
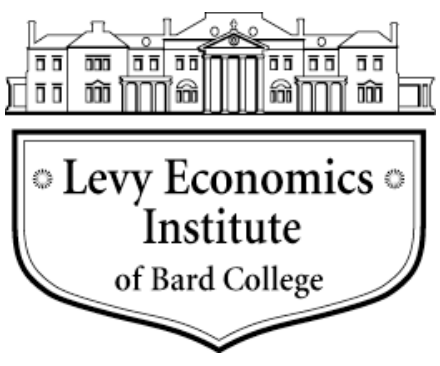

Working Paper No. 861

\title{
Money, Power, and Monetary Regimes
}

by

Pavlina R. Tcherneva

Levy Economics Institute of Bard College

March 2016

The Levy Economics Institute Working Paper Collection presents research in progress by Levy Institute scholars and conference participants. The purpose of the series is to disseminate ideas to and elicit comments from academics and professionals.

Levy Economics Institute of Bard College, founded in 1986, is a nonprofit, nonpartisan, independently funded research organization devoted to public service. Through scholarship and economic research it generates viable, effective public policy responses to important economic problems that profoundly affect the quality of life in the United States and abroad.

\author{
Levy Economics Institute \\ P.O. Box 5000 \\ Annandale-on-Hudson, NY 12504-5000 \\ http://www.levyinstitute.org
}

Copyright (C) Levy Economics Institute 2016 All rights reserved

ISSN 1547-366X 


\begin{abstract}
Money, in this paper, is defined as a power relationship of a specific kind, a stratified social debt relationship, measured in a unit of account determined by some authority. A brief historical examination reveals its evolving nature in the process of social provisioning. Money not only predates markets and real exchange as understood in mainstream economics but also emerges as a social mechanism of distribution, usually by some authority of power (be it an ancient religious authority, a king, a colonial power, a modern nation state, or a monetary union). Money, it can be said, is a "creature of the state" that has played a key role in the transfer of real resources between parties and the distribution of economic surplus.

In modern capitalist economies, the currency is also a simple public monopoly. As long as money has existed, someone has tried to tamper with its value. A history of counterfeiting, as well as that of independence from colonial and economic rule, is another way of telling the history of "money as a creature of the state.” This historical understanding of the origins and nature of money illuminates the economic possibilities under different institutional monetary arrangements in the modern world. We consider the so-called modern "sovereign” and “nonsovereign” monetary regimes (including freely floating currencies, currency pegs, currency boards, dollarized nations, and monetary unions) to examine the available policy space in each case for pursuing domestic policy objectives.
\end{abstract}

Keywords: History of Money; Monetary Sovereignty; Chartalism; Counterfeiting; Public Monopoly; Currency Issuers vs. Currency Users; Exchange Rate Systems

JEL Classifications: B5, E6, E42, E63, F45, N1, Z1 


\section{INTRODUCTION}

Few institutions are as important to human welfare as the institution of money. Fewer still are as grossly misunderstood. Our knowledge and understanding of what money is, where it comes from, and what it does is littered with pervasive myths. ${ }^{1}$ Among these myths are: 1) that money is a creature of the market born out of the necessity to facilitate barter; 2) that money is an object, usually of some intrinsic value (derived from precious metals) that is easily transportable and divisible; and 3) that in and of itself, money has little economic significance (it is "neutral"), serving only to simplify transactions but leaving employment, consumption, and investment decisions unaffected.

These myths pervade mainstream economic theory and are known as the "Metallist view" of money (Goodhart 1998). They lead to several problematic assumptions and methodological practices within economics. First, since money is considered to be a market phenomenon, the state's control over the monetary system is treated as a significant market intervention that reduces market efficiency. ${ }^{2}$ Second, if money is an object of intrinsic metallic value, it is assumed to be inherently scarce. From here, due to this scarcity, it is argued that government spending crowds out private consumption and investment. Additionally, the state's monopoly power over the currency issue is seen as a consequence of the state's appropriation of private monies that must be constrained at all costs, as the state (it is claimed) has the perverse incentive to overspend and debase the currency. Finally, because money is "neutral," conventional economic models are entirely void of money, finance, debt, or default.

Though the Metallist view of the origins of money dominates mainstream economics, it finds no support in any of the academic literature from history, anthropology, numismatics, sociology, Assyriology, religion, and other. Debunking the conventional story is crucial, as it upends all of the above propositions and illuminates the modern monetary system in ways the conventional view cannot do.

\footnotetext{
${ }^{1}$ The use of the term "money" itself has been problematic, as it means different things to different people. Some economists use it to refer to liquidity, others treat it strictly as an object, yet others emphasize its abstract nature as a unit of measure. This paper aims to remedy this confusion.

${ }^{2}$ See work on the inefficiency of seigniorage (Freeman 1993).
} 
This paper presents a historically grounded analysis of the origins of money to illustrate that money predates markets. Not only is it not a "creature of the market," but a strong case can be made that money is instead a "creature of the state," however broadly defined. This proposition stands at the heart of the Chartalist (or Modern Money) approach to money. This paper extends an earlier analysis of Chartalism (Tcherneva 2006) and defines money as a power relationship of a specific kind, namely a social credit-debt relationship, that is codified by some authority or institution of power — be it an ancient religious authority, tribal chief, or an early administrative body, such as a Mesopotamian palace or a Greek polis, and later a monarchy, colonial power, or a modern nation state. Far from being a simple medium of benign exchange, the history of money as a creature of the state indicates that it is instead a means of distribution, a tool of transferring real resources from one party to another, subject to the power relationship of the specific historical context.

\section{ON MONEY AND POWER}

A historical journey through the origins of money indicates that money is first and foremost a social relationship. More precisely, it is a power credit-debt relationship, whereby the indebted party issues a liability that is held by the creditor as an asset. Behind this social relationship lay varied social power relationships that codify human behavior in the specific historical context and cultural and religious norms that govern the process of social provisioning.

There are several accounts of the historical origins of money. Economists commit a basic error when they conflate the origins of money with the origins of coinage (Innes 1914: 394; Knapp 1924: 1). The story of money's emergence from some hypothetical market exchange based on barter relationships finds no support in any other discipline outside of economics.

It is a well-established fact that money predates minting by nearly 3,000 years. Clay tablets (the earliest discovered forms of money) and various other kinds of instruments which bear no 
"intrinsic" value had circulated for thousands of years before the emergence of coinage or trade. ${ }^{3}$ Indeed, clay tablets are themselves early checks or balance sheets, where the markings on the tablet specify how the debt can be extinguished (for example, a King's Check would be inscribed "Say to NN to give X to the bearer"), the collateral for the debt (someone's son or daughter), or the terms of debt slavery and bankruptcy.

\section{Mesopotamian Origins}

Assyriologists trace the origins of money to Mesopotamian temples and palaces, which developed an elaborate system of internal accounting of credits and debts (Hudson 2003). These large public institutions played a key role in establishing a general unit of account and store of value (initially for internal record keeping, but also for administering prices). Money, in a sense, evolved as a public good introduced by public institutions in the process of standardizing prices and weights.

\section{Wergild}

There is evidence that money also originated in ancient penal systems that instituted compensation schedules of fines, similar to wergild, as a means of settling one's debt for inflicted wrongdoing to an injured party (Grierson 1997; Goodhart 1998; Wray 1998). These debts were settled according to a complex system of disbursements, which were eventually centralized into payments to the state for crimes. Subsequently, the central authority (be it a religious body, a tribal chief, or a political organization) added various fines, dues, fees, and taxes to the list of compulsory obligations of the population.

These two stories are not mutually exclusive. Since a system of debts for social transgressions existed in pre-Mesopotamian societies, it is highly likely that the measurements of social obligations (debts) were also used to measure equivalencies between commodities (Ingham 2004: 91). Henry’s (2004) analysis of ancient Egypt also bridges the first two accounts.

\footnotetext{
${ }^{3}$ By "trade" here we mean "exchange" in the conventional sense-a market mechanism where prices serve an allocative role. Trade, in one form or another, has existed since very early times, and predates money itself. What is important about early trade is that, given available information, there was no attempt to establish "equal" trade ratios (Henry 2004; Graeber 2011).
} 


\section{Ancient Egypt}

In Egypt, as in Mesopotamia, money emerged from the necessity of the ruling class to maintain accounts of agricultural crops and accumulated surpluses, but it also served as a means of accounting for payment of levies, foreign tribute, and tribal obligations to the kings and priests. ${ }^{4}$ Henry (2004) argues that before societies were able to produce surplus, they had no use for money. Indeed, a substantial transformation of social relations from egalitarian tribal society to one that is stratified and hierarchical was needed before money emerged. Once agricultural developments generated economic surplus, taxation was used by authorities as a method of transferring part of that surplus (the real resources) from the population to the palaces. The central authority (the king) levied taxes on the population and determined how they could be settled by establishing the unit of account used to denominate all debts to the state (Henry 2004).

One of these units of account in the Old Kingdom was the deben, but no debens ever changed hands. It was a purely virtual and abstract measure for standardizing weights and prices, much like in the Mesopotamian palaces, though many different things represented one deben-wheat, copper, labor, etc. That is, once the unit of account was established, many "things” measured in debens started circulating as means of payment.

Graeber (2011) makes a compelling case that, indeed, for most of human history, money has been "virtual." Today, the "dollar" is also an abstract unit of measure and there are many things that answer to the name "dollar"-notes, coins, and (mostly) electronic digits. Keynes also recognized that money is first and foremost a virtual state-administered unit of account, where the state has also been able to determine its physical form for at least 4,000 years.

\footnotetext{
${ }^{4}$ Henry (2004: 90) further adds that money cannot exist without power and authority. Societies based on hospitality and exchange simply had no use for it, while in a stratified society the ruling class is compelled to devise standard units of account, which measure not only the economic surplus collected in the form of taxes, but also the royal gifts and religious dues that were imposed on the underlying population.
} 
The State, therefore, comes in first of all as the authority of law which enforces the payment of the thing which corresponds to the name or description in the contract. But it comes doubly when, in addition, it claims the right to determine and declare what thing corresponds to the name[...] This right is claimed by all modern States and has been so claimed for some four thousand years at least. [...]To-day all civilized money is, beyond the possibility of dispute, chartalist. (Keynes 1930: $4-5)$

\section{Religious Practices and Redistributive Justice}

In Ancient Greece, as in Ancient Egypt, the emergence of money was closely tied to need of religious authorities to control the flow of surplus. In other words, money becomes a public mechanism of distribution of economic surplus and justice. Semenova (2011: ii) explains:

[In Ancient Greece] money emerged in the context of [...] socioeconomic hierarchies and inequalities. Money was first embodied in the portions of sacrificial bull's flesh distributed by religious authorities during the rituals of communal sacrificial meals. Purporting to allocate to each his "just" and "equal" share, the redistributive rituals created a façade of social justice and equality via the use of money.

In sum, power, taxation, and religious tribute play a crucial role in all of these accounts of the origins of money. Taxation is the motor behind the transfer of real resources from subjects to authority. Money is the vehicle. The resource transfer was partly to provision the authority itself, and partly to allow the authority to redistribute the surplus to its subjects more "equitably" within the context of the cultural and religious social mores of the time. In a sense, money is a creature of the state, a public good, and a redistributive mechanism employed by that state for good or ill. 


\section{ON THE MYTH OF BARTER}

In contrast to the historical account above, economists embrace the pervasive but historically unsubstantiated myth of barter. ${ }^{5}$ Indeed, the definitive work from Cambridge anthropologist Caroline Humphrey (1985: 48) is steadfast in its conclusion: "No example of a barter economy, pure and simple, has ever been described, let alone the emergence from it of money; all available ethnography suggests that there never has been such a thing."

Barter arrangements of course did exist, but they were never a coordinating mechanism for social provisioning in any society. Graeber (2011: 37) suggests that barter itself is most likely a modern and temporary phenomenon, observed among people familiar with the use of money, but who (for one reason or another) experience a breakdown in those monetary arrangements.

Debunking the myth of barter is key as it debunks the notion that money emerges from voluntary market transactions where agents engage in mutually beneficial exchange where no single agent has any power over the other, and where the state introduces sizable market imperfections and inefficiencies. Because money is a social power relationship, the socially embedded story of money tells us that it emerges as a public good, within the complexity of historically specific social debt obligations, whereby an authority serves as the arbiter of private and public debts, the agency which determines the unit of account (how all debts will be measured), and the enforcer of those debt settlements. That authority is the institution that imposes non-reciprocal obligations on the population and that assumes a redistributive role-in some cases in the interest of "fairness" and "justice," while in other cases in the interest of colonization and slavery (more below). Placing power, authority, or some social agency that administers and enforces monetary debt arrangements at the center of the history of money also helps us understand modern monetary systems, and the powers and responsibilities of nation states to fulfill their redistributive functions.

\footnotetext{
${ }^{5}$ In the conventional view in economics, money emerges from barter as a means to solve the double coincidence of wants. Economists present these origins as a purely hypothetical (even fictional) example of a barter system. Menger (1892) recognized the lack of historical evidence supporting the Metallist view and therefore posed a different question: "even if money did not originate from Barter, could it have?" He thus aimed to "perfect" the conventional view of money by offering a mathematical solution to the hypothetical scenario of barter.
} 
The importance of the historical record is: 1) to delineate the nature of money as a social debt relationship; 2) to stress the role of public institutions in establishing a standard unit of account by codifying accounting schemes, price lists, and private and public debts; 3) to show that in all cases money was a pre-market phenomenon, representing initially an abstract unit of account and means of payment during a complex process of social provisioning, and only later a generalized medium of exchange; and 4) to underscore its inherent quality as a vehicle of redistribution. The next task is to use this historical understanding to illuminate modern monetary regimes and the policy space available for pursuing economic goals.

\section{MODERN MONEY}

The precise origins of money will never be known to us, but we know that it cannot be understood outside the powers of some authority or arbiter. In the modern context, however, money is not only a public good, but it is also a simple public monopoly. Modern nation states, like their ancient counterparts, also impose compulsory debts on the population and determine how they will be settled. But now they also have the exclusive power to issue the very thing that settles those debt obligations (even if they abdicate this power, as is the case of some countries today). Private sector attempts to interfere with this power (for example through counterfeiting) are some of the most heavily prosecuted private offenses (more below).

\section{Taxes}

In the modern context, taxes assume an additional role. They still serve as an instrument of transferring real resources from the private to the public sector, but the way this transfer occurs is by creating demand for government-issued fiat currency. Modern governments settle their debts and pay for their expenditures by issuing their own liabilities—reserves, notes, coins, government checks. The private sector, facing a series of compulsory obligations to the state, denominated in the state-administered and state-issued unit of account, must obtain the currency before it can settle its debts to the state. Obviously, the issuer (the government) cannot collect taxes in currency it has not already issued. The way the private sector obtains currency from the issuer is by offering labor, goods, and services for sale to the state, paid in state currency. 
In other words, in the modern context, taxes have two functions. First, they create demand for otherwise worthless paper currency (Mosler 1997-98; Wray 1998). Second, they serve as a means of provisioning the government in real, not in financial, terms. A monopoly currency issuer is never financially constrained by tax collections, as it always pays by issuing more of its own liabilities. It can spend as much currency/reserves as it wishes, so long as there are real goods and services for sale. And the state cannot possibly collect currency through taxes before it has provided it through spending. The state does not need "tax money" to spend; it needs real resources. A welfare state in particular needs an army, public school teachers, a police force, food inspectors, and any other resources necessary to fulfill its public purpose. In a way, the modern state, as in ancient Greece, continues to serve a redistributive function in the economy, where it collects real resources (labor) from the private sector, and then redistributes them back to the private sector "more equitably" in the form of infrastructure, public education, government research and development, and via any other social welfare functions it has been asked to fulfill by voters. The role of taxation in modern market economies remains the same as in ancient times: it is not a “funding mechanism,” but a "real resource transfer mechanism.”

\section{Launching New Currencies}

Because taxes create demand for the currency, they have also been used as vehicle for launching new currencies. This can occur even in cases when the sovereign government has been unable to fulfill its duties to the public by using its own national currency. For example, throughout the 1990s Argentina operated under a monetary regime called a “currency board,” which required the nation to maintain a fixed-exchange rate with the dollar, thereby abdicating monetary sovereignty and subjecting public spending decisions to the maintenance of the peg.

This arrangement severely constrains the ability of the government to spend national currency (pesos, in this case). New pesos in Argentina could be put in circulation only after the acquisition of foreign exchange (US dollars) held in central bank coffers. Argentina's government had to either earn or borrow dollars first before it could increase its spending in pesos. As a net importer, Argentina bled dollars throughout the 1990s, thereby reducing the amount of pesos in circulation, asphyxiating the economy and plunging it into what is now known as the Argentinean "lost decade.” 
To deal with this economic crisis, Argentina's provinces used their constitutional power to issue notes, thereby circumventing the problem with the national currency shortage. The new notes (patacones or lecops, for example) began circulating overnight, even though the Argentineans themselves did not "trust" the currency and there were no legal tender laws that required people to use it.

Instead, the provinces allowed the public to pay its state taxes and public utility bills in the new notes, and in turn paid state employees with that new script. Taxes were a sufficient condition to create demand for a new fiat currency, and the provinces had to spend the currency before they could collect it in taxes. Taxes did not finance these provinces, instead they gave states more policy space to spend and conduct internal policy by launching these new currencies. The notes quickly circulated throughout the private economy and were used until the currency board was abandoned, monetary sovereignty in pesos was restored, and the Argentine government embarked on an aggressive expansionary economic policy. This episode demonstrates that taxes do not finance the spending of the issuer of the currency; instead they serve as an effective vehicle for launching that new currency.

Taxes are also a powerful coercive mechanism. In Africa, for example, newly imposed head taxes compelled the colonized African tribes and communities to use the currency of the colonial powers and became another method of colonialization and resource extraction (Rodney 1972; Ake 1981). Whereas, the local population previously had no use for the colonial currency, with the imposition of taxes on the local population denominated in British pounds, French francs, or other colonial currency, tribes began to sell crops and labor in exchange for the colonial currency in order to settle the new tax obligation. It is, therefore, no surprise that the process of independence of any nation from colonial rule has been accompanied by the implementation of a new independent national currency, or with the assumption of full sovereign control over an existing national currency.

\section{Monetary Sovereignty as a Prerequisite for Political Sovereignty}

One way to tell the story of "money as a creature of the state" is to examine the process of achieving national independence. The very formation of the modern nation state has been 
inextricably linked with the process of establishing a unified sovereign national currency, which underscores the salience of having the ability to conduct the internal affairs of a nation, independently from external influence (usually, that of a former colonial power). Often, the former colonial power would slow down the process of political independence in two ways: 1) by instituting monetary arrangements that would undermine it (e.g., currency boards); or 2) by outright sabotage of the monetary system (e.g., via counterfeiting). We explore each of these obstacles in turn.

Take the example of the former British colonies. As the British Empire began dissolving, newly independent nations began acquiring full monetary sovereignty. India, for example, had been issuing its own notes-rupees_-since 1862 (while still under British rule), but for most of that period up until independence the monopoly note issue in India operated like a currency board (Weintraub and Schuler 2013). Only after independence did India assume full sovereign control over the rupee. Similarly, Australian colonies gradually began issuing some notes, but they were all pegged to the pound sterling. The peg continued even after Federation in 1901, up until the time the government assumed control over all currency matters and began issuing the Australian pound in 1910. Full independence required independent monetary sovereignty, which Australia finally achieved in the interwar period.

The colonies remained tethered to the British Empire, through currency boards and hard peg currency arrangements, keeping them dependent on monetary policy in the United Kingdom. In order to expand the domestic money supply, colonies had to export real goods and services to the former colonial power in exchange for the foreign currency (British pounds), against which they were pegged.

In a sense, the currency board was a method of continued colonial exploitation —an ongoing extraction of real resources and real goods and services, in exchange for foreign reserves. The board severely constrained the abilities of independent nations to conduct internal macroeconomic policy, so long as they promised convertibility of their national currencies into another. To complete the process of independence, colonies understood that monetary 
sovereignty was indispensable. Over time, they abandoned these currency regimes (hard pegs and currency boards) and expanded the policy space to implement domestic policy.

\section{Counterfeiting}

The case of the US colonies' pursuit of independence is similar in many ways-having political sovereignty necessarily meant acquiring monetary sovereignty as well, a process which the British forces tried to undermine unsuccessfully through currency counterfeiting, i.e., a method of financial warfare.

Economists have no theory of counterfeiting. Because money is seen as a medium of exchange emerging from barter, the very limited writing on counterfeiting only examines the question of whether it may be “efficient” (Kultti 1996). In general, counterfeiting is treated as a marginal and unimportant phenomenon that is not theorized.

The process of political independence of the US colonies went hand in hand with the process of monetary independence. As soon as the colonies declared independence and started the Revolutionary War, they began issuing their own currency to finance the war effort. The overissuance of continentals is often used as an example of currency mismanagement by governments, leading to the swift depreciation of fiat currency from overspending. And while it is true that financing the Revolutionary War required the colonies to increase their spending at a rapid rate, a much underappreciated fact is that the depreciation was much more the result of counterfeiting than overspending. ${ }^{6}$

Currency issue in the US colonies began 85 years before independence, as the colonies understood the need to emit the very thing that circulated within the colony for settlement of private and public debts (Rhodes 2012). These currency experiments worked reasonably well and gave the colonies significant economic independence, which prompted the British Empire to retaliate with the Currency Acts of 1751 and 1764, prohibiting the issue of new currency by the colonies.

\footnotetext{
${ }^{6}$ The Continental Congress had issued a massive amount of notes to finance the war and some depreciation would have likely occurred anyway, but probably not enough to cause the total demise of the continental currency.
} 
As soon as war was declared, colonies began to issue notes again, which they believed was their sovereign right. Several months before the war, however, British forces as well as crown loyalists in the Americas flooded the colonies with counterfeit notes. As Rhodes (2012: 35) put it: "On the Eve of the Revolution, American counterfeiting had surpassed British imperialism as the No. 1 threat to Colonial currency.”

After independence, the various attempts at launching a unified national and exclusive currency failed when President Jackson vetoed the recharter the Second Bank of the United States. Simultaneously, notes issued by individual states proliferated. And so did private counterfeiting. State chartered bank notes multiplied to 10,000 different kinds, 6,000 of which were regularly falsified (Rhodes 2012). When Lincoln’s Legal Tender Act of 1862 designated the greenback as the national currency, counterfeiting remained widespread, even though it now carried significantly greater risks. The American colonies initially failed to crack down on northern printers; eventually the Treasury (established in 1789) began prosecuting counterfeiting of national currency with the full force of the law (Rhodes 2012), but it took a while to perfect the law enforcement process. In 1865, the Secret Service (authorized by Lincoln) was created precisely for the defense of this exclusive sovereign power- to issue the national currency_and was charged with cracking down on counterfeiting.

Benjamin Franklin recognized that, as much as issuing one’s own currency is a prerequisite for sovereignty and independent internal policy, counterfeiting was an act of war against the Sovereign (Rhodes 2012). Sabotaging the exclusive prerogative to issue the currency was done by devaluing it via massive overissuance and by the inability to distinguish between the sovereign and counterfeit notes.

Counterfeiting as an act of war has been used in other cases. Such are the cases of governmentsponsored counterfeiting of German reichsmarks by the British during WWI (Cooley 2008), of US dollars by Stalin in the interwar period (Krivitsky 2011), of British notes by Hitler during WWII (operation Bernhard), and of Vietnamese and Cuban currency by the US during the Vietnam War (Asselin 2013: 189) and the failed Bay of Pigs invasion (Cooley 2008), respectively. 
Revisiting stories of counterfeiting makes for tantalizing reading, but they are theoretically important. As long as money has existed, so has counterfeiting. Numismatic work shows that counterfeiting of coins emerged as soon as the oldest coin was struck in Lydia (7th century BCE) via clipping, shaving off, or melting, and all were punishable by death.

Counterfeiting was a problem in nonmetallic money too. Indeed capital punishment for forgery of bank notes was part of the legal code in England as late as the 18th century (Desan 2015). This is why, for example, the split tally stick had such an original design to avoid it. In medieval Europe, taxes were often levied in the form of wooden tallies, whereby the payments were recorded with notches on the stick that was then split in half (lengthwise). This way the two halves both recorded the same notches, and the taxpaying serf kept one as proof of his tax payment.

Clay tablets were also difficult to forge, as they represented detailed and complex schedules of tax assessments and payments, other debts obligations, and price equivalences. But it is likely that there have been attempts to tamper with their value as well, which necessitated the creation of the bulla (a seal where clay tokens were stored). The image (face value) of the clay tokens was often imprinted on the wet surface of the clay seal (the bulla) before it dried, to ensure that once the seal was broken to make payment, the value contained inside matched exactly the value claimed by the payee.

In other words, for most of known history, as long as money has existed as a creature of the state, private interests have wanted to manipulate its value. That is, a history of counterfeiting is a history of money as a creature of the state. It is a history of the ability of an authority to impose nonreciprocal obligations, set the unit of account for their payment, and enforce them. In the modern context, it is also a story of establishing a unified national currency for the purposes of independently conducting a nation's domestic affairs.

Because economic theory does not recognize money as a creature of the state, it also has undertheorized the importance of monetary sovereignty. Economists see counterfeiting as an irregularity from generally smooth functioning markets (Kultti 1996). If, however, money is 
correctly considered as a creature of the state, then counterfeiting becomes a pervasive privatesector market phenomenon that requires theorization. And as long as money has been a public good, the responsibility for both maintaining its purchasing power and for providing it in a manner consistent with domestic goals has rested with the government.

\section{Hierarchy of Money}

The focus so far has been on state-issued liabilities and state-administered units of account. But it is important to note that, since money is a debt/IOU, anyone can issue IOUs (Minsky 1986). The problem, as Minsky argued, is to get them accepted. And indeed in modern capitalist economies, private agents finance their activities with position-making instruments—privately issued liabilities, which have varied degrees of acceptability. Banks create bank money at the stroke of a pen via the process of lending. As the endogenous approach to money stresses, loans create deposits, which in the aggregate create purchasing power from private credit. In modern financial systems, central banks stand behind the liabilities of the banking sector to maintain a sound payments system and accept bank liabilities for payment of taxes, thereby making them as equally acceptable as state-issued liabilities.

The Chartalist approach stresses that the multitude of private-sector liabilities can be ranked in a hierarchical fashion, whereby the most acceptable and liquid forms of debt sit atop the money pyramid (Bell 2001).

\section{Figure 1. The Hierarchy of Money}

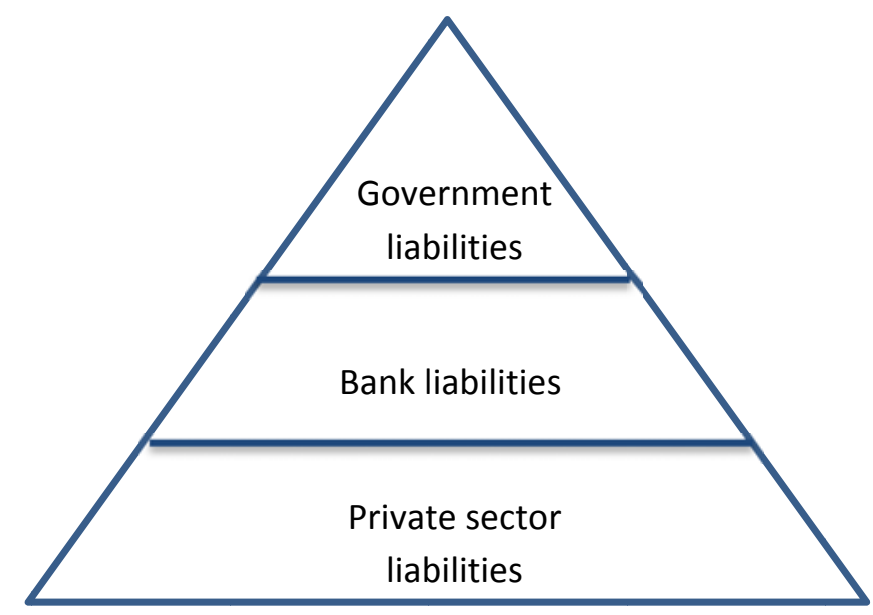


The most important feature of this pyramid is that every economic unit, except the government, has to deliver a third party's IOU (that sits somewhere higher in the pyramid) to settle its debt obligations. Firms and households settle their debts by delivering checks (bank liabilities) or notes and coins (central bank or Treasury liabilities). Banks settle debts among each other by delivering reserves (central bank liabilities). The government is the only economic unit that settles its own debts by issuing more of its own liabilities. The state issues several types of liabilities: some are issued by its monetary agency (notes and reserves) and others are issued by its fiscal agency (coins, Treasury checks, and Treasury securities). The issue of each of these liabilities is the exclusive sovereign monopoly power of the state. The payment of one liability (Treasury check or Treasury security, for example) takes place when the state delivers another one of its liabilities (reserves).

While private contracts and debts clear in the state-issued unit of account (reserves), it is private finance that drives the capital development of modern market economies. It is also private finance that causes frequent financial and economic instability (Minsky 1986), but the final responsibility for the stability of the financial system rests with the state.

A capitalist system is a financial system, argued Minsky (1986). It is an evolving and innovating system, continually looking for new profitable opportunities by creating markets for new privatesector liabilities. Banks create new position-making instruments, either for the purpose of financing the capital development of the economy or for financing "finance." The process of funding the acquisition of real or financial assets adds another dimension of instability to the capitalist system, and the process of financial innovation is often accompanied by creative accounting practices and fraud.

From this vantage point, as legal theories of finance illustrate, financial markets are essentially hybrid systems (neither private nor public), neither purely of the state nor purely of the market. However, the law and its enforcement rest with the state, as private and public debt commitments are enshrined in law (legal contracts). Pistor (2013) argues that in the throes of a financial crisis, when the full enforcement of legal commitments would result in the self-destruction of the financial system, the full force of the law is suspended to ensure the survival of the financial 
system and prevailing financial relations: "Where law is elastic,” she states, “power becomes salient” (Pistor 2013).

When Knapp proclaimed that "money is a creature of law” (1973 [1924]: 1), he did not say that “money is a creature of legal tender law” (as in Schumpeter 1954: 1090). Indeed Knapp explicitly rejected such an interpretation. Money is a creature of law because the state is the adjudicator and enforcer of nonreciprocal obligations and other private-sector contracts.

\section{MODERN MONETARY REGIMES}

“One nation, one currency” is the norm in modern economies (Goodhart 1998), where nation states assume full sovereign monopoly control over the currency issue. We nevertheless observe multiple cases of varying degrees of sovereignty, where states voluntarily impose on themselves different monetary restrictions or abdicate their monetary sovereignty altogether. From here, we can classify monetary regimes according to the different degrees of monetary sovereignty. At one end of the spectrum are fully sovereign monetary regimes. These are cases where the state issues non-convertible freely floating national currency and the two agencies of governmentthe central bank and the treasury (or ministry of finance) — coordinate to clear government payments and guarantee all state liabilities that are denominated in the domestic currency. In these cases, the ability to execute internal domestic policy does not depend on the shortage of government finance, but on political considerations and the availability of real domestic resources that can be transferred to the public sector for the purposes of achieving these objectives. ${ }^{7}$ It must be noted that even fully sovereign monetary regimes have institutional peculiarities_-laws and practices that may constrain government spending according to some self-imposed or legacy rules (for example, debt ceiling requirements in the US or the inability of

\footnotetext{
${ }^{7}$ Note the emphasis on achieving domestic goals with domestic real resources. Countries like the US, which enjoy reserve-currency status, have the ability to acquire many foreign-produced real resources that counties without such a status do not. But the foregoing analysis does not depend on the reserve currency status of a nation. "Sovereignty" here means that the issuer of the currency cannot be forced into an involuntary default in its own currency. It also means that the sovereign can, irrespective of the nation's external position, employ whatever domestic resources are available for domestic goals. Resource-poor countries may not have sufficient real domestic resources, which may necessitate the purchase of foreign exchange that will in turn have implications for the value of the domestic currency. But again, it will not necessitate an involuntary default in the domestic currency.
} 
the Treasury to run an overdraft on its account at the Fed). But even in these cases, the rules are regularly suspended or circumvented when the policy priorities dictate that the government must spend beyond these artificial constraints (think of the Federal Reserve creating a "treasury supplement"- essentially another account for the Treasury-at the stroke of a pen after the 2008 financial crisis, or of the routine practice of raising the debt limit in the US on as-needed basis, political wrangling notwithstanding).

Other countries, however, face hard financial constraints in executing domestic policy. At the other end of the spectrum are countries that have completely abdicated monetary sovereignty, thus giving up the right to issue and manage their own national currency. This is the case of dollarized nations (Ecuador and small Caribbean nations, for example) and member states in the European Monetary Union. In both cases, relinquishing monetary sovereignty has transformed those countries from "currency issuers” into “currency users.”

To spend, the government of Ecuador must either earn or borrow dollars first. In this case, tax collections do raise revenue for the government. As an oil-exporting nation, Ecuador has not yet faced a dollar shortage, even though it has pursued aggressive development and pro-growth policies, while simultaneously strengthening the welfare safety net. But with a gradual liberalization of financial markets and an increased standard of living in Ecuador, one can envision a future when the country becomes a net importer, losing foreign exchange (dollars) faster than it earns it, and thereby experiencing a monetary contraction and an overall deflationary environment.

This of course is the case in the periphery countries of the eurozone (EZ). They gave up their national currencies when they joined the monetary union. The situation is similar to that of Ecuador because, to conduct expansionary domestic policy, EZ governments must earn or borrow euros first. Net exports become the main channel for increasing a country’s euro holdings (a strategy that describes the case of Germany, for example), but should a nation find itself in a net importing position, thereby losing euro reserves (as is the case in the periphery), the only way to fund government programs is by borrowing euros, by raising domestic taxes for revenue, or by cutting those programs. The latter two have contractionary effect, which undermines the 
governments' ability to pursue its policy agenda further. The former (raising revenue through borrowing) puts the periphery nations at the mercy of the private market's willingness to finance these already heavily indebted nations. It also puts the periphery countries in a vicious Ponzi finance cycle, where more heavily indebted nations face rising costs of borrowing, thereby increasing their overall indebtedness, while further undermining their ability to repay their debt.

The EZ has tried to "solve” its economic problems by becoming a net exporter vis-a-vis the rest of the world. It is well understood that net exports cannot be a global solution to economic problems (as for every net exporter there must be a net importer), but within the EZ itself, it is highly likely that there will always be some countries that are in a net importing position.

Because the European Central Bank (ECB) is prohibited from financing EZ members by purchasing their government debt (the way the Bank of Japan or the Bank of England do, for example), the EZ lacks a fundamental mechanism for executing independent macroeconomic policy. Thus, member nations have given up unprecedented policy space to pursue domestic priorities, including the maintenance of some basic public-sector functions or the implementation of pro-growth stimulus policies as needed. At the same time, the EZ as a whole lacks a central fiscal mechanism to conduct euro-wide economic policy, as is normally the case in other monetary unions with a full monetary sovereignty (as in the US, Canada, or Australia). Countries that fall in between the two extremes (full monetary sovereignty and no monetary sovereignty) will have different degrees of policy space available to them. They can be ranked as follows, from the most to the least amount of policy space: 1) nonconvertible freely floating sovereign currency regimes as discussed above (US, Japan, UK, Canada, most countries in the world). In practice, these are often managed or dirty float systems, as central banks intervene in currency markets; 2) pegged floats, where the domestic currency is pegged to a foreign currency at a specific value or within a band. These are either fixed or periodically adjusted, and vary from crawling bands to crawling pegs to pegged within a horizontal band; 3) fixed exchange rate regimes, which promise direct convertibility into a foreign currency at a predetermined rate; 4) currency boards, a much stricter form of a fixed exchange rate system, where the monetary authority operates on autopilot to fulfill absolute and unlimited convertibility between its notes and the foreign currency; and, finally, 5) dollarization; and 6) monetary unions. 
Figure 2: Modern Monetary Regimes and Policy Space

Nonconvertible sovereign free float (and dirty float)

Pegged float (crawling band, crawling peg, horizontal band)

Fixed exchange rates

Currency board

Dollarization

Monetary union
Greatest policy space

$\downarrow \quad$ Smallest policy space

As long as a nation commits to convertibility, it will depend (to various degrees) on acquiring someone else's national currency (foreign reserves) for expanding the domestic issue. The goal of maintaining a stable exchange rate with the foreign currency will often conflict with other policy objectives, which will impede efforts to deal with recessions or bank crises. For this reason, fixed exchange rate regimes are often abandoned in the middle of severe economic and financial crises, freeing additional policy space to conduct independent macroeconomic stabilization monetary or fiscal policy.

In fully sovereign monetary regimes, however, the economic possibilities before a nation with a freely floating nonconvertible national currency are constrained largely by political considerations and the availability of real resources to achieve those priorities, not by the availability of money.

The final issue to address, then, is how can this policy space be used by a monetarily sovereign government for achieving various policy goals? The answer to the question will also help us debunk the final of the three myths from the start of this paper, namely that money is neutral and that, in and of itself, it does not affect employment and production decision.

\section{MONEY MATTERS}

A discussion of the full range of economic possibilities under sovereign monetary regimes is beyond the scope of this paper. We will single out one problem that merits consideration, as it is pervasive, persistent, and pernicious - the problem of unemployment. Nations with different 
degrees of monetary sovereignty have different capacities to address this problem, but what is frequently overlooked is that unemployment in a market economy is itself a result of current monetary arrangements.

Unemployment is a monetary phenomenon. From the point of view of firms it means that, in the aggregate, expected costs and proceeds do not justify the employment of any more individuals than firms are already employing. This is the effective demand problem identified by Keynes (1936). Note that effective demand can still be deficient (in the sense that profit expectations do not warrant any more hiring) even in a very strong economy. Firms are simply not in the business of providing jobs for all. They can be neither expected nor required to attain and maintain full employment over the long run.

That is the job of government. And that is because "unemployment" is in a certain sense created by government. From the point of view of households, unemployment is evidence of someone wanting but not being able to obtain the currency. Recall that the tax that creates demand for the currency immediately creates unemployment. The population is required to fulfill a nonreciprocal obligation with currency it does not have. The source of that currency is the government. Thus the private sector provides real goods and services (labor) to the government in exchange for that currency. The tax creates a demand for government-issued money by creating unemployment in that currency (that is, labor which seeks remuneration). It is therefore incumbent on the monopoly issuer to provide its currency in a manner that is consistent with the objectives of full employment and price stability.

Recall that the government is also responsible for assuring that the currency is sound. Modern currencies are in part "valuable" because the state keeps them in a constant state of scarcity, as evidenced by mass unemployment. But there is an alternative. The state can provide its currency in a manner that allows people to freely access it, while ensuring some internally stable floor for its value (Mosler 1997-98).

As the monopoly issuer of the currency, the state has the privilege of setting the prices for the goods and services it receives in exchange for the currency. But the state need not set all prices. 
It is sufficient to fix only one of them (the price of labor, for example) to anchor the value of its currency. Chartalists suggest that an ongoing public program that offers employment to anyone ready, willing, and able to work at a base wage can do the job (see the employer of last resort, job guarantee, and buffer stock employment proposals). Such a program will fluctuate countercyclically with the business cycle-expanding as private business hiring declines and shrinking as private-sector employment picks up. The base wage will become the nominal anchor that establishes a conversion rate between the currency and labor.

While currency values are themselves very complexly determined, they essentially reflect what one can buy with the currency. The hourly wage of the buffer stock program pins down a basic conversion rate between labor and the currency. In other words, say, a $\$ 10 /$ hour wage in the program would anchor the currency in labor power and set the value of the dollar to be equal to six minutes of work. If the wage were doubled, then as a benchmark one dollar will exchange for three minutes of work (or will erode in value by half). So when the emitter of the currency (the government) sets the exchange rate between the currency and the labor in the countercyclical buffer stock pool, it helps stabilize the value of its currency (for details, see Mosler 1997-98; Wray 1998; and Tcherneva 2012).

Freely floating nonconvertible currencies today have no equivalent anchors. A full discussion of the program is beyond the scope of this paper. Our aim is merely to point out that, in a world where the currency is a simple public monopoly: 1) unemployment is evidence that the currency is in short supply; 2) the tax itself creates unemployment by creating private demand for the monopolist's currency; 3) the monopolist has the power to set a conversion rate between its currency and labor hours; 4) the monopolist can provide the currency on an as-needed basis by maintaining the internal anchor; and 5) the buffer stock employment program can be used to create socially useful output, thereby allowing the monopoly currency issuer to fulfill its redistributive functions in a way that serves the public purpose. 


\section{CONCLUSION}

This paper began by defining money as an evolving social power relationship in the process of social provisioning. The development of "private monies" was not emphasized, not because it is unimportant (far from it), but because the role of the authority in codifying private contracts and transactions has been pervasive throughout time. From its inception, money has been a "creature of the state,” however broadly defined. Because of its unique power to impose compulsory obligations on its subjects and set the terms of their repayment, the state has always played some redistributive role in the process of social provisioning. This redistributive function is intrinsic to the state, irrespective of whether it is used for the good of the many or the good of the few.

In modern capitalist economies the currency is a simple public monopoly, and competitive market-clearing models based on the neutrality of money are wholly inapplicable to the study of the monetary system. Nevertheless, the pervasive mainstream economic myths about the origins and nature of money have alleged that the state’s power over the monetary system is an unwarranted intrusion with significant disruptive effects. These myths have also given rise to monetary arrangements (such as currency boards or monetary unions) that radically constrain the policy options before modern nation states.

Not only can the birth of money not be divorced from the powers of the state, but the entire monetary system resides within the set of rules and legal code set forth by the state. Yet monetary regimes like the European Monetary Union have forced an incoherent divorce between nation states and their national currencies at great economic and human costs.

A proper understanding of the origins, role, and functions of money is essential for adequate assessment of contemporary economic problems and the policy space available to address them. It prompts us to think about the possible ways in which one could employ the monopoly powers of the state and design public policies to achieve a wide range of policy objectives, including full employment and price stability. 


\section{REFERENCES}

Ake, C. 1981. A Political Economy of Africa. Essex, England: Longman Press.

Asselin, P. 2013. Hanoi's Road to the Vietnam War: 1954-1965. Berkeley, CA: University of California Press.

Bell, S. 2001. "The Role of the State and the Hierarchy of Money." Cambridge Journal of Economics 25: 149-63.

Cooley, J. 2008. Currency Wars: how forged money is the new weapon of mass destruction. New York, NY: Skyhorse Publishing.

Desan, C. 2015. Making Money: Coin, Currency and the Coming of Capitalism. Oxford, UK: Oxford University Press.

Freeman, S. 1993. “The Inefficiency of Seigniorage from Required Reserves.” Research Paper No. 9334, Federal Reserve Bank of Dallas.

Goodhart, C.A.E. 1998. "The Two Concepts of Money: Implications for the Analysis of Optimal Currency Areas." European Journal of Political Economy 14: 407-32.

Graeber, D. 2011. Debt: The first 5000 years. London, UK: Melville House Publishing.

Grierson, P. 1997. The Origins of Money. London, UK: Athlone Press.

Henry J.F. 2004. “The Social Origins of Money: The Case of Egypt.” In L.R. Wray (ed.) Credit and State Theories of Money. Cheltenham, UK: Edward Elgar.

Hudson, M. 2003. “The Creditary/Monetary Debate in Historical Perspective.” In S. Bell and E. Nell (eds.) The State, the Market and the Euro. Cheltenham, UK: Edward Elgar.

Humphrey, C. 1985 “Barter and Economic Disintegration.” Man, New Series 20(1): 48-72.

Innes, A.M. 1913. “What is Money?” Banking Law Journal May: 377-408.

Ingham, G. 2004. The Nature of Money. Cambridge, UK: Polity Press.

Keynes, J.M. 1930. A Treatise on Money. London, UK: Macmillan.

Keynes, J.M. 1936. The General Theory of Employment, Interest and Money. New York, NY: Harcourt-Brace \& World.

Knapp, G.F. [1924] 1973. The State Theory of Money. Clifton, NY: Augustus M. Kelley.

Krivitsky, W.G. 2011. In Stalin’s Secret Service. New York, NY: Enigma Books. 
Kultti, K. 1996. “A Monetary Economy with Counterfeiting.” Journal of Economics 63(2): 17586.

Menger, K. 1892. “On the Origin of Money.” Economic Journal 2(6): 239-55.

Minsky, H.P. 1986. Stabilizing and Unstable Economy. New York, NY: McGraw-Hill.

Mosler. W. 1997-98. "Full Employment and Price Stability.” Journal of Post Keynesian Economics 20(2): 167-82.

Pistor, K. 2013. “A Legal Theory of Finance.” Journal of Comparative Economics 41(2): 31530.

Rhodes, K. 2012. “The Counterfeiting Weapon.” Federal Reserve Bank of Richmond, Econ Focus, First Quarter 16(1): 34-37.

Rodney, W. 1972. How Europe Underdeveloped Africa. Washington, DC: Howard University Press.

Schumpeter, J.A. 1954. History of Economic Analysis. Oxford, UK: Oxford University Press.

Semenova, A. 2011. "Would You Barter With God? Why Holy Debts and not Profane Markets Created Money.” American Journal of Economics and Sociology 70(2): 376-400.

Tcherneva, P.R. 2006. "Chartalism and the Tax-Driven Approach to Money.” In P. Arestis and M. Sawyer (eds.) Handbook of Alternative Monetary Economics. Northampton. MA: Edward Elgar.

Tcherneva, P.R. 2012. “Employer of Last Resort.” In J.E. King (ed.) The Elgar Companion to Post Keynesian Economics. Northampton, MA: Edward Elgar.

Weintraub, C. and K. Schuler. 2013. “India’s Paper Currency Department (1862-1935) As a Quasi Currency Board.” Studies in Applied Economics December(9): 1-27. Available at: http://krieger.jhu.edu/iae/economics/Indias_Paper_Currency_DepartmentWorkingPaper. pdf [Accessed August 16, 2015]

Wray, L.R. 1998. Understanding Modern Money: The Key to Full Employment and Price Stability. Cheltenham, UK: Edward Elgar. 